\title{
The Nuée Ardentes of Sabalan Volcano in Iran
}

\author{
Reza Fahim Guilany, Ali Darvishzadeh, Seyed Jamal Sheikhzakariaee* \\ Department of Geology, Science and Research Branch, Islamic Azad University, Tehran, Iran \\ Email: *j.sheikhzakaria@gmail.com
}

How to cite this paper: Fahim Guilany, R., Darvishzadeh, A. and Sheikhzakariaee, S.J. (2016) The Nuée Ardentes of Sabalan Volcano in Iran. Open Journal of Geology, 6, 1553-1566.

http://dx.doi.org/10.4236/ojg.2016.612110

Received: December 1, 2016

Accepted: December 20, 2016

Published: December 23, 2016

Copyright $\odot 2016$ by authors and Scientific Research Publishing Inc. This work is licensed under the Creative Commons Attribution International License (CC BY 4.0).

http://creativecommons.org/licenses/by/4.0/

\begin{abstract}
This article deals with the introduction and explanation of the two nuéeardentes of "Mue'el Valley" and "Shirvandareh Valley" which are one type of the pyroclastic flows of Sabalan volcano. One of the features of nuéeardente in these two valleys is the presence of large blocks in upstream of valley and the abundance of ash in downstream which it has happened in one stage in Mue'el and in several stages in Shirvandareh Valley. Considering the antiquity of the great Sabalan volcano and numerous changes that have happened during these long years in the region, determining the temperature of nuéeardente was impossible. But what could be mentioned as a sign of high temperature because of nuéeardente is the presence of rust ground mass on piece levels which indicate hot water steam $\left(500^{\circ} \mathrm{C}\right.$ to $\left.600^{\circ} \mathrm{C}\right)$. Also puzzle breakings like those in these rocks should be the result of severe explosion blast and very fast movements of nuéeardente that has broken these rocks instantly. These nuéeardentes are peléan type and they are more or less synchronous, and the main reason could be the huge explosion which happened because of the second caldra's subsidence. By comparing deposits of the two nuéeardentes of Mue'el Valley and Shirvandareh Valley, it is observed that the extent, thickness, and size of blocks are higher in Shirvandareh than those in Mue'el Valley. Also considering higher levels of pieces' adherence and hardness of deposits, it can be concluded that the temperature of this complex was higher than that of Mue'el Valley, and in general the power of Shirvandareh's nuéeardente is more than the Mue'el Valley's.
\end{abstract}

\section{Keywords}

Pyroclastic Flow, Nuée Ardente, Caldera, Dome Growth, Sabalan

\section{Introduction}

Sabalan is a stratovolcano with andesitic, trachy andesitic, and dacitic composition [1] [2] [3] [4] in the northwest part of Iran, $40 \mathrm{~km}$ southwest of Ardabil, $25 \mathrm{~km}$ southeast of Meshkinshahr, and located in the north part of eastern Azerbaijan province (Figure 1). 


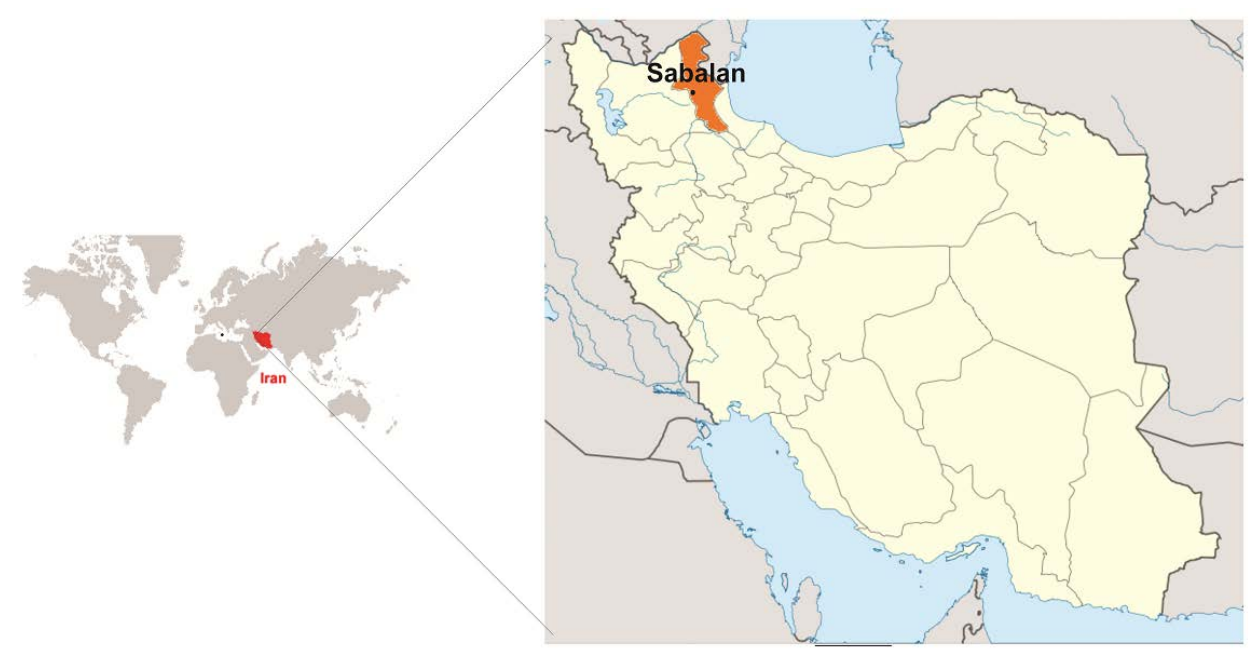

Figure 1. The situation of Iran and Sabalan is shown in geographical map.

Sabalan Volcano Mountains start from Gharesou from the northwest of Ardabil city and continue in the east west direction in $60 \mathrm{~km}$ length and $48 \mathrm{~km}$ width to the Ghoushe Dagh Mountain in the south of Ahar city and have three peaks; the taller peak is called "Sabalan Soltan" and two others are called "Heram Dagh" or Sabalan-e Kuchak and "Aghan Dagh" or Kasra (Figure 2). These three peaks are rested on volcanic rocks which researchers call them pre-caldera series [1] [3] and the estimated area is about $1200 \mathrm{~km}^{2}$. The researchers who studied Sabalan volcano have considered the formation of caldera as the base for categorizing its important events and have divided volcanic activities of Sabalan into two sets: pre-caldera and post-caldera or paleo-Sabalan's series and neo-Sabalan that its main explosive activity has been after the collapse of caldera. In this time along or immediately after explosive activity, domes and lava flows have been extricated and formed the highest parts of central Sabalan. The combination of these domes and lavas is trachy andesite and dacite [1] [5]. In these cases, by caldera's formation the growth of dome was limited to the breakings of caldra which are intense explosive kind [6]. Accordingly and considering the fact that the last eruptions of Sabalan are more or less synchronous with the formation of the second caldera; the age of the second caldera should be 110,000 years [2] which is almost synchronous with the formation of nuéeardentes of Mue'el valley and Shirvandareh valley.

Sabalan has two overlapping falling calderas. The bigger one's diameter is $20 \mathrm{~km}$ and the smaller one's is $12 \mathrm{~km}$. In this case, Sabalan is considered among the 20 great volcanoes of the world [1].

The history of Sabalan's activity is very old and different researchers [2] [3] [7] [8] have related Sabalan volcano's activity to $4 / 5$ to 6 million years ago. From that time until now, it has erupted in different forms such as volcano type (large amounts of blocks), plinian type (extended pyroclastic fall deposits), peléan type (nuéeardente deposits), and even ultra-plinian. During these eruptions around $14 \mathrm{~km}^{3}$ amount of pyroclastic deposits have left. This vast amount of pyroclastic deposits is specific to the volcanoes of subduction zone [9]. 


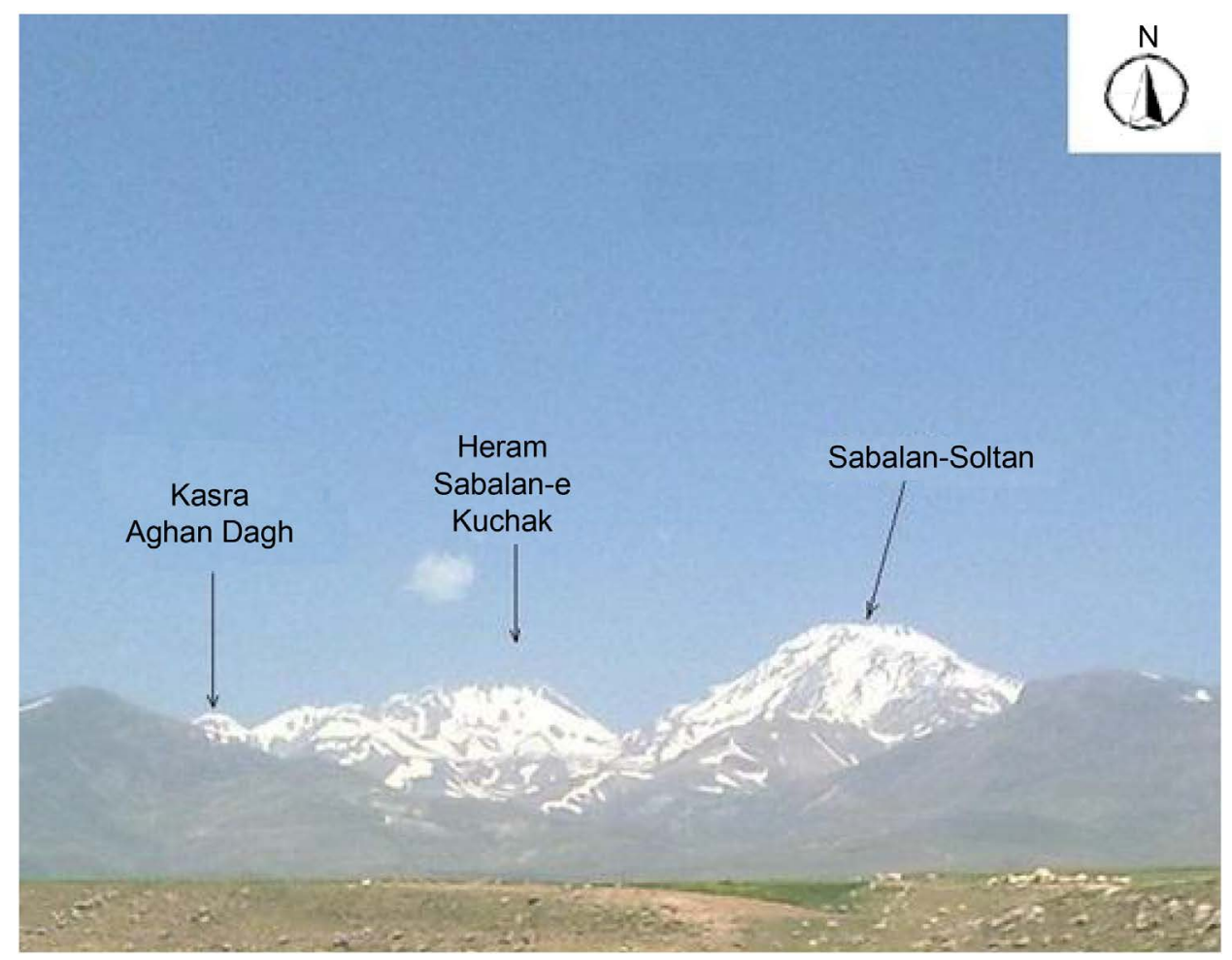

Figure 2. Three peaks of Sabalan volcano.

One of the most famous and destructive types of pyroclastic flows is nuéeardente. Nuéeardente is an old term that has been largely replaced by "pyroclastic flows" or more recently "pyrolastic density current" [10]. For the first time, nuéeardente was used by [11] [12] for describing a flow of hot cloud, ash, and rock which in the $8^{\text {th }}$ of May 1902, descended from Mount Pelée's peak in Martinique Island and destroyed Saint-Pierre port and its inhabitants [13]. Nowadays, it is used as a fundamental example that from its specific features is very strong explosion and creating a flow of hot gases along with ash and dust and rubble which moves along the valley and destroys everything in its way.

The observations which we have reached to in field studies, leftovers from Sabalan volcano, are some traces from nuéeardente in two fault valleys; one is Mue'el valley 9 $\mathrm{km}$ northwest of Sabalan peak which because of its large extension was worse and more destructive than Mount Pelée's nuéeardente. This happened at least more than 110,000 years ago that is the age of Sabalan volcano's last activity [2] when the area certainly had no inhabitant. The other one Shirvandareh valley is located $20 \mathrm{~km}$ southeast of Meshkinshahr and between Lahroud city and Sabalan. These explosions happened respectively in the western edge and north of caldera.

Despite studies that have been done about this plio-quaternary volcano, only the petrology and geochemistry of its volcanic rocks were discussed, and no discussion has yet been done about types of pyroclastic deposits which is a significant portion of volume of this huge mountain. Given that such a study has not been done about Sabalan or other volcanos of Iran, the activity history of this great volcano can be simulated by 
studying pyroclasts. Hence, this paper deals with explaining these two nuéeardentes the traces of which are still left.

\section{Methods of Study}

\subsection{Methods and Materials}

The base of this research is the observations which we reached to in field studies, the leftovers from Sabalan volcano. Geologists who work on volcanic rocks usually have only a limited conception of the techniques utilized to study recent unconsolidated pyroclastic. Many of the problems encountered in this study are similar to those found in sedimentary rocks, where grain size, grain shape, and geometry of deposits must be the tools of determining the physical processes controlling their formation and deposition.

\subsection{The Geographical Location of Mue'el Valley and Shirvandareh Valley}

Mue'el valley is located in northwest of Sabalan and approximately $7 \mathrm{~km}$ of the main Sabalan Mountain and by a village with the same name (Figure 3). This tight and narrow valley is of southern northern direction, most of which has been filled with pyroclastic deposits that are known as "Mue'el" formations.

This formations start from top of the valley between Aghandagh and Jenvardagh that its traces are still visible (Figure 4) and it has moved at the northwest foot of Sabalan heights, and after passing valley's length and accumulation it has moved to southwest part of the city and ends up in Meshkinshahr plain. Its length is $19 \mathrm{~km}$, its width is around 1.5 to $2.5 \mathrm{~km}$, and the average thickness of its deposits is around $120 \mathrm{~m}$ and it forms a mass around 2 to $2.5 \mathrm{~km}^{3}$ [1].

Aside from the beginning point, the other sections of this formation have smooth surfaces, and its tilt decreases regularly on the way to Meshkinshahr valley, but in the end it gets a somewhat steep slope.

The Khiavchai River flows in this valley and has affected this formation and created deep cuttings in it (Figure 5). For this reason and considering weakness and lack of strength of the mentioned formation, deeper valleys are drilled and mostly they have reached to basement rock, that is, Sabalan's primary volcanic rocks.

The fault valley of Shirvandareh has greater dimensions than Mue'el Valley (Figure 3). Its estimated length is $30 \mathrm{~km}$ and its average width is $2.5 \mathrm{~km}$, but its depth is not recognizable because it has been stocked with different pyroclastic deposits. The filling deposits of this valley according to age are as follows: nuéeardente deposits, coarsegrained pyroclasts, ignimbrite of Shirvandareh and fall ash deposits with different thicknesses.

This valley is located around $20 \mathrm{~km}$ southeast of Meshkinshahr and between Lahroud city and Sabalan, its altitude from sea level is $2200 \mathrm{~m}$, and its estimated area is around $75 \mathrm{~km}^{2}$. From the south part to the northern foot of Sabalan (Heram), from the east to Lahroud-Shabil road, from the west to Houshang Meidani, and from the north it leads to the lands of Ghoulchanghlou village. 


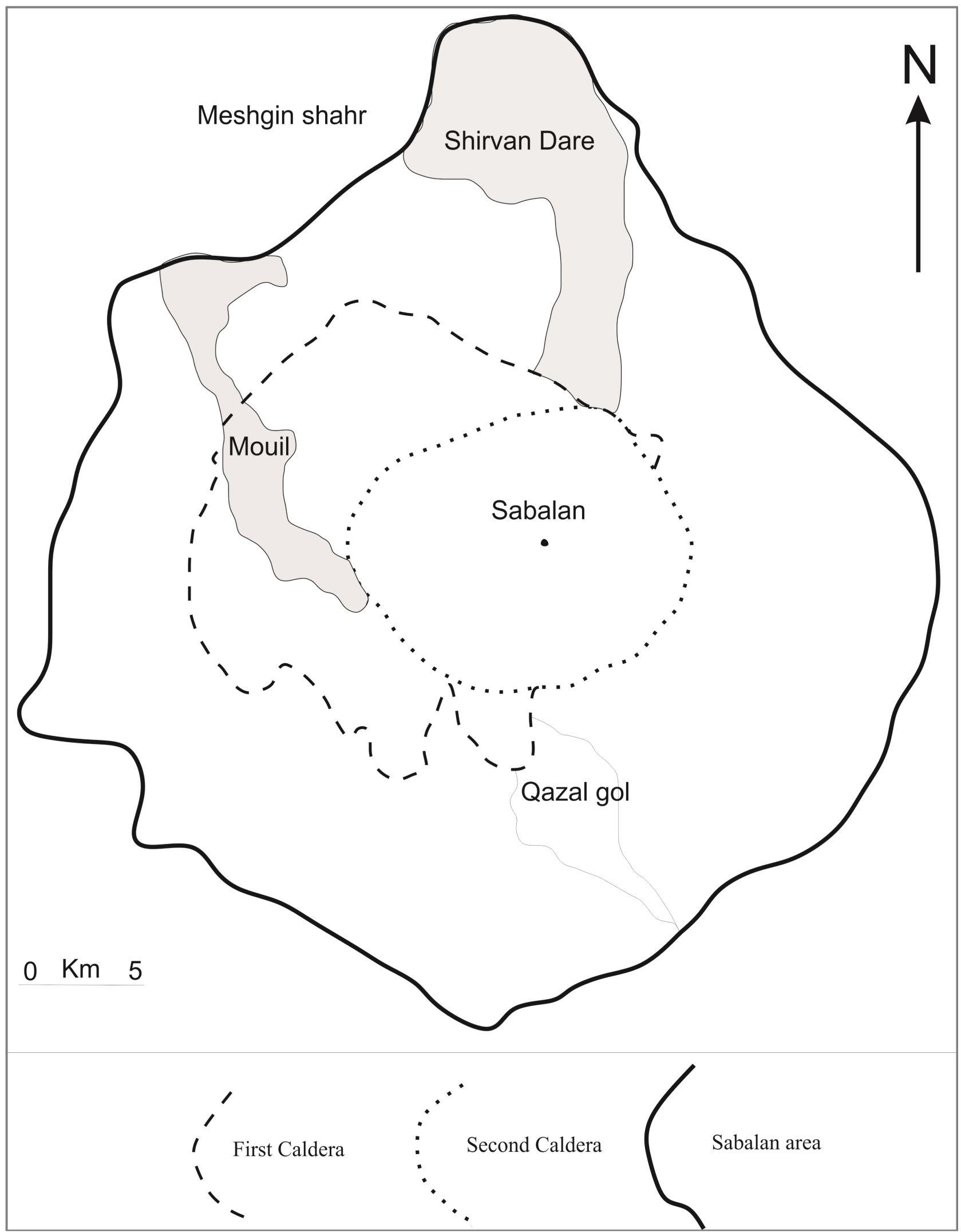

Figure 3. The path of the two nuéeardentes of Mue'el and Shirvandareh. 


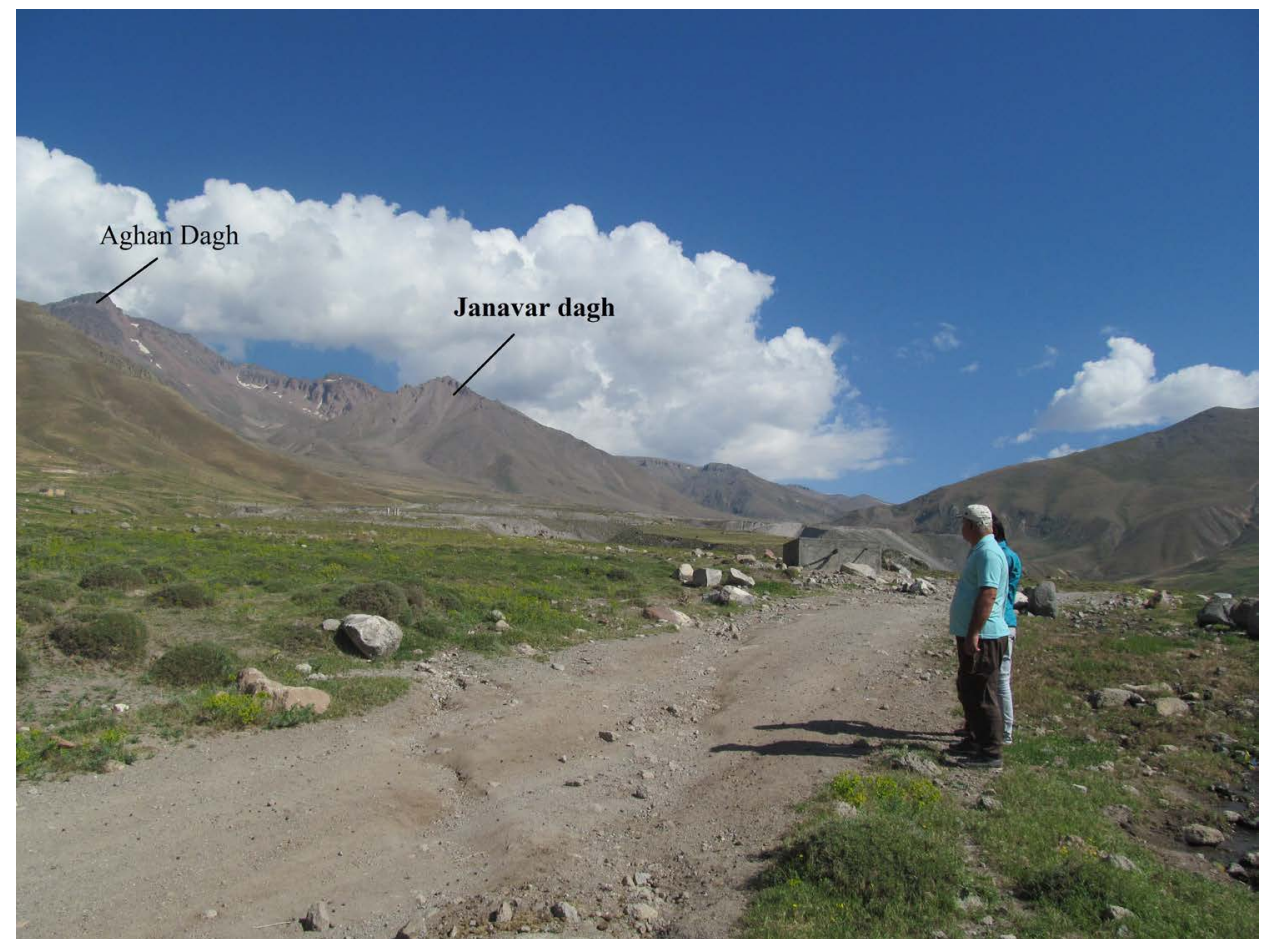

Figure 4. The beginning point of Mue'el Valley nuéeardente between Aghandagh and Janavardagh.

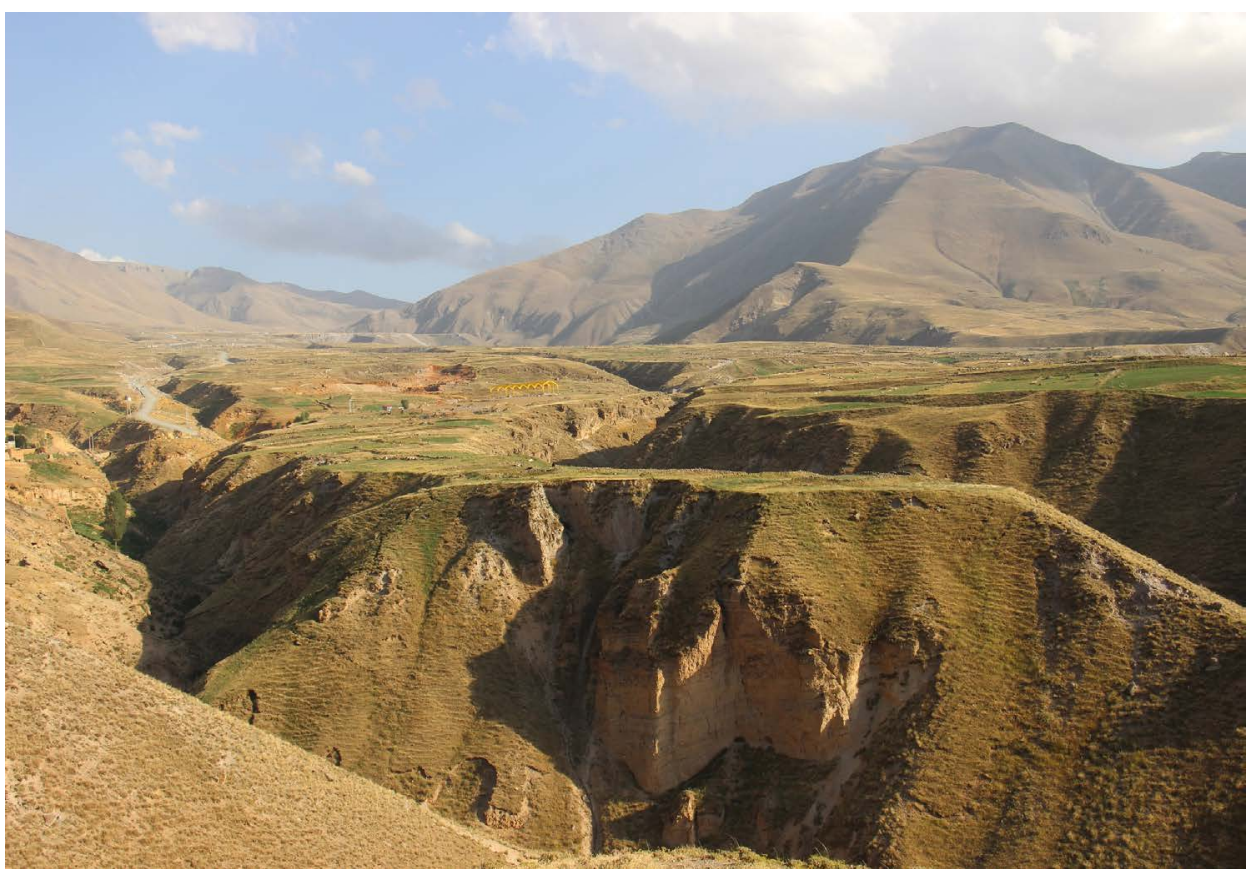

Figure 5. Mue'el Valley's floor is filled with nuéeardentes deposits.

Shirvandareh is narrow at the beginning, and the side walls of the valley have vertical slope with the estimated height of $100 \mathrm{~m}$. But while moving gradually toward Lahroud, the valley gets deeper and side walls' height decreases. 


\section{Results}

The nuéeardentes of Sabalan Volcano are the result of the peléan type explosion of Aghandagh Mount which happened because of the second caldera's subsidence. In fact, at the same time with the second caldera subsidence, gassy lava in magma chamber came under pressure and through the fractures was thrown out and created three-stage nuéeardente in Shirvandareh valley and another one in Moeil valley.

By comparing deposits of the two nuéeardentes of Mue'el Valley and Shirvandareh Valley, we observe that the extent, thickness, and size of blocks (presence of pieces larger than eight tons) are higher in Shirvandareh than in Mue'el Valley. Also considering higher levels of pieces' adherence and hardness of deposits, it is believed that the temperature of this complex was higher than Mue'el Valley, and generally the power of Shirvandareh's nuéeardente is more than Mue'el Valley's.

\section{Discussion}

\subsection{Nuée Ardente of Mue'el Valley}

The ingredients of Mue'el formation have a very fixed scene; both laterally and also along its entire length. The majority of mentioned ingredients are formed of relatively loose joined breccia with highly variable grading and bad sorting.

These pyroclastics have magmatic origins, and blocks are placed in a matrix of ash and basically scattered along the valley and its splits. One of the specifications of mentioned pyroclastsis the presence of fragments as big as a few square centimeters to a few square meters which consist $10 \%$ to $20 \%$ of this formation. The mentioned fragments have smooth and rounded appearance, and it seems they have lost their edges due to rolling and colliding. The blocks are mainly rocky and mostly dome rocks of Aghandagh and Janavardagh and actually belong to pre-caldera volcanic rocks which have been detached due to explosion and moved along the valley.

The matrix in mentioned rocks, which are scattered has a larger mass and is fundamentally made up of relatively coarse-grained ashes in light yellow, orange to light brown, and very small shattered pieces (Figure 5).

As mentioned, these materials form a very heterogeneous mixture with no sorting; whether vertically or horizontally.

In the upper side of Mue'el Valley (beginning of the valley), pyroclastic deposits had more erosion, so their traces could be seen through numerous fairy chimneys in this part (Figure 6).

With the above explanations, it can be imagined that the old part of Aghandagh dome was detached after the last terrible explosion which formed Mue'el Valley's nuéeardente and a new dome, that the present Aghandaghis developed from it.

Lava dome-forming eruptions vary in style and can produce a variety of extrusive features from blocky pelean-type domes (typically andesite to dacite), thick coulees and tortas (typically dacite to rhyolite), to low-viscosity coulees and flows (typically basalt to basaltic andesite) [14]. On the other hand, [6] believes great explosive eruptions with greater explosion $\mathrm{VEI} \geq 4$, also some of the most important and destructive explosions 

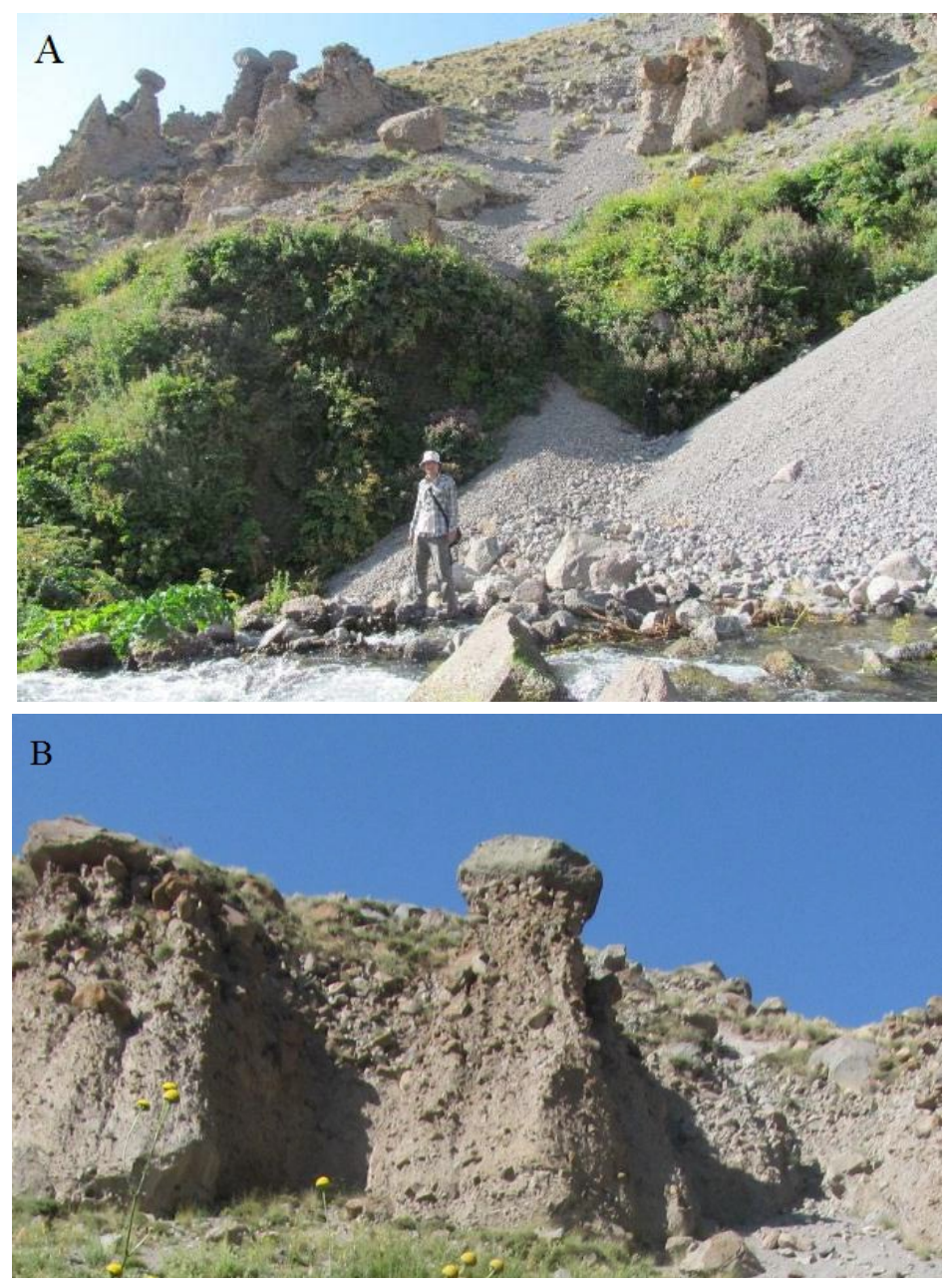

Figure 6. (A) and (B) the traces of erosion and formation of fairy chimney.

of the $20^{\text {th }}$ century were in relation with the growth of lava dome. Some of the most important examples of these is the VEI 4 eruption of Mount Peléein 1902 [11], the VEI 5 eruption at Mount St. Helens in 1980 [15] [16], the VEI 4 eruption at Mount Merapi in 2010 [17] [18].

But what has happened in Mue'el Valley by considering the very different shape of grains, unsortedness, and mass fluidity which moved in Mue'el Valley and its expansion to Meshkinshahr suggests their rapid replacement in an explosive and destructive level. This type of formation is usually introduced by the name pyroclastic flow.

The presence of breccias and ashes on the foot of surrounding valleys which nowadays are $100 \mathrm{~m}$ above the formation of Mue'el, suggests the very rapid and explosive replacement of nuéeardente pyroclastics of Mue'el and it seems a part of rock and ash mixture along with hot gases with fast movement and floating over Earth's surface has pursued the path of valley bottom.

Considering the antiquity of the great Sabalan volcano and numerous changes that have happened during these long years in the region, determining the temperature of nuéeardente was impossible. But what could be mentioned as a sign of high tempera- 
ture because of nuéeardente is the presence of rust ground mass on piece levels which indicate hot water steam $\left(500^{\circ} \mathrm{C}\right.$ to $\left.600^{\circ} \mathrm{C}\right)$. Also puzzle breakings like those in these rocks should be the result of severe explosion blast and very fast movements of nuéeardente that has broken these rocks instantly (Figure 7).

The beginning point of this pyroclastic flow is an exceptional one, because it is located in the intersection of two important tectonic events of Sabalan region. At the moment in the upper part of this fault valley (Shafa and Mue'el) hot springs exist that are used by passengers during summer days.

According to the above explanations, Mue'el Valley's nuéeardente is the result of peléan type explosion of Aghandagh Mount and in the vicinity of Sabalan peak. In this explosion, a mixture of gas, lava drops along with the ashes, and relatively big rock pieces that are mainly Aghandagh and Jenvardagh rocks exit with high speed and temperature $\left(500^{\circ} \mathrm{C}\right.$ to $\left.600^{\circ} \mathrm{C}\right)$ from the crater. The mentioned mixture under gravity force in valleys tilts moves with the speed of around $200 \mathrm{~km}$ in an hour and in the vicinity of the soil. It destroys everything in its way. The blocks on the upper side and granule pieces and ashes are resided at the end of the valley.

\subsection{Nuée Ardente of Shirvandareh}

Shirvandareh is at the end of the north of Sabalan and at the intersection of the two Sabalan calderas; both old and new (Figure 3). This valley is filled with different pyroclastic flows, but its surface is rougher in comparison to Mue'el Valley (Figure 8) and the reason is related to the vast width of this valley which has created a numerous and complicated hydrographical network there. On the other hand, the higher heterogeneity of building blocks and tectonic movements which has influenced Shirvandareh formation has been effective in this heterogeneity. Also in the upper part of the traces of erosion, it could be seen as numerous fairy chimneys (Figure 9).

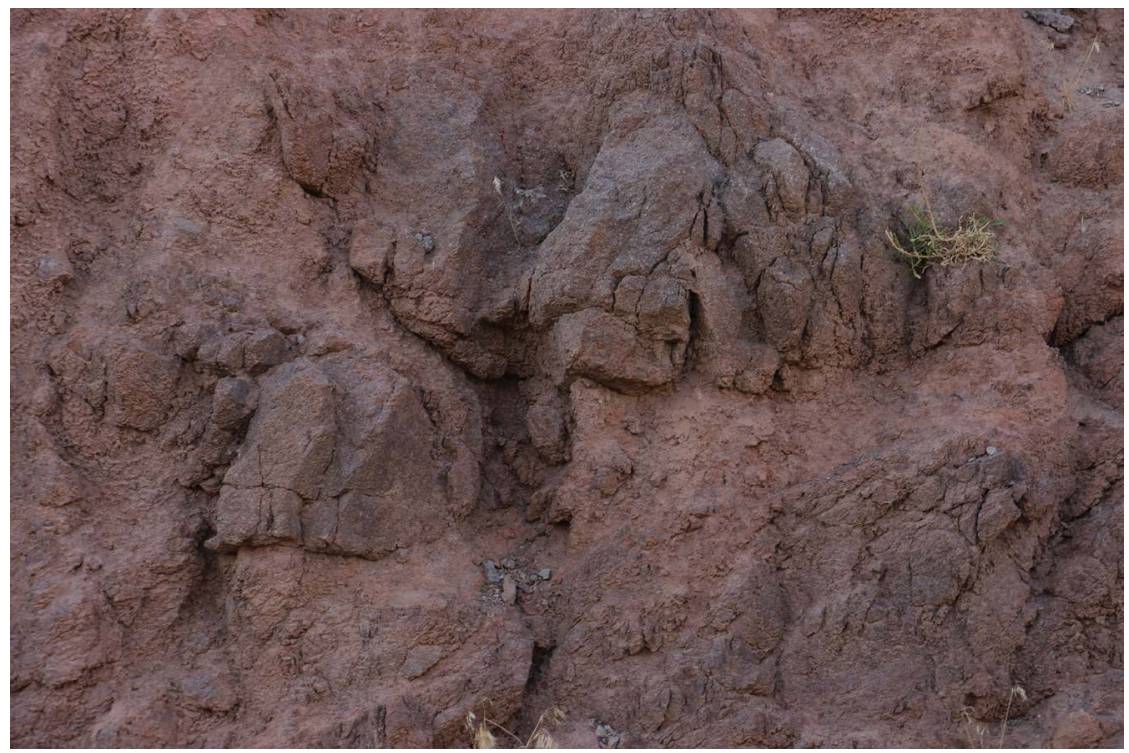

Figure 7. Rust ground mass on piece level due to high temperature of nuéeardente. 


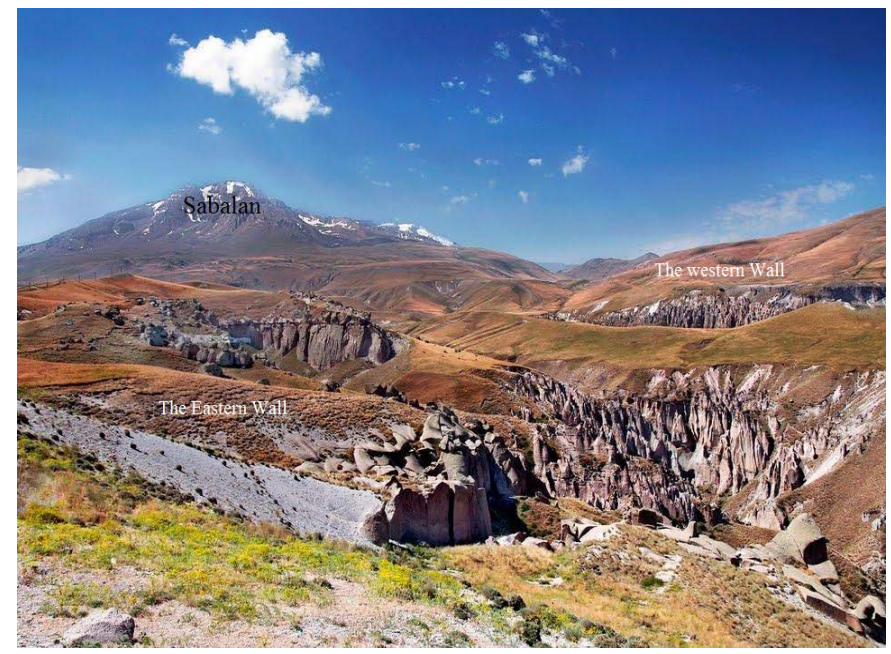

Figure 8. The upper part of Shirvandareh which is filled with nuéeardente deposits.
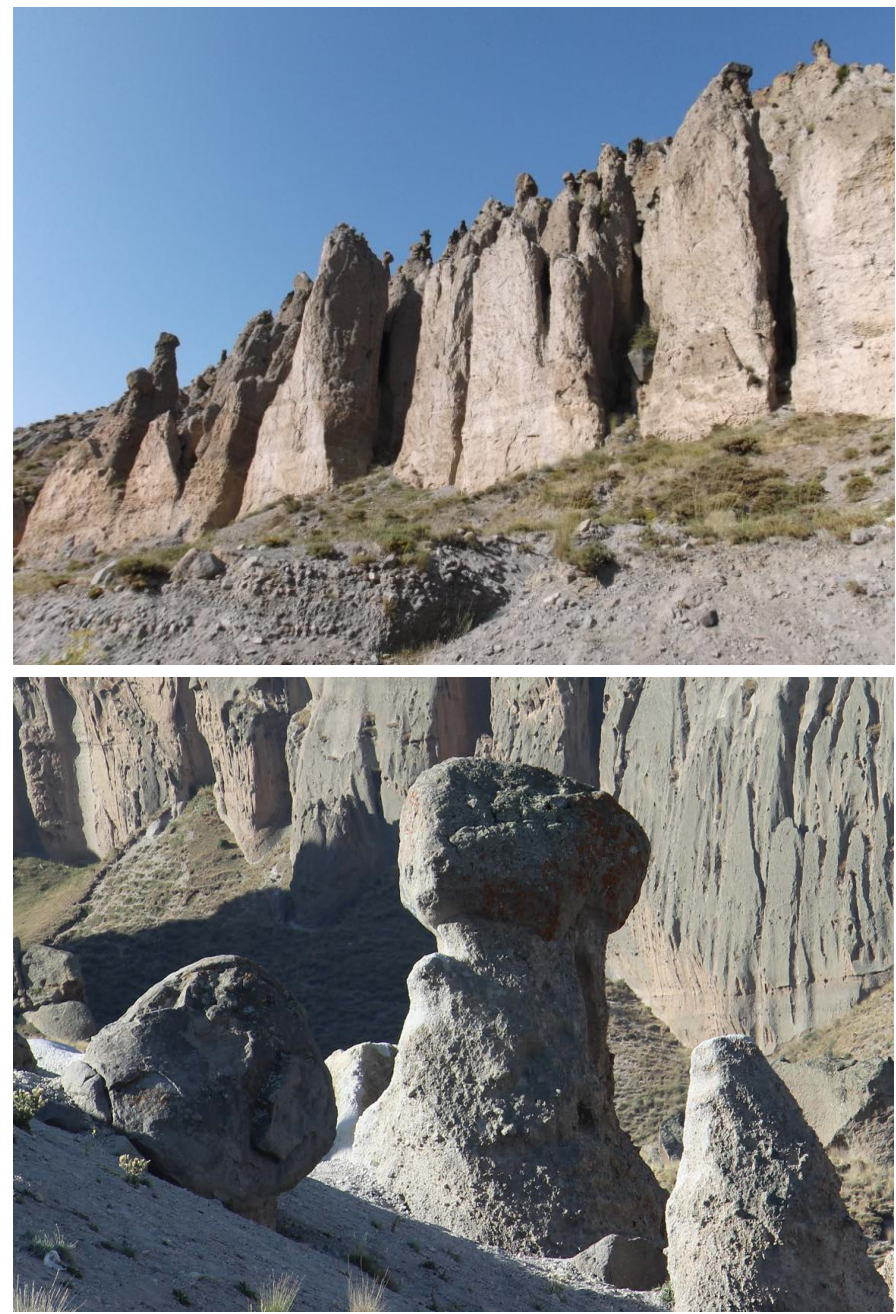

Figure 9. Traces of erosion and formation of fairy chimney in the upper part of nuéeardente'spyroclastics of Shirvandareh. 
The total volume of the deposits that has filled Shirvandareh is around 5 to $6 \mathrm{~km}^{3}$ [1]. These deposits have magmatic origins and there exist large blocks (up to several square meters) in a matrix of very small grains. The number of large blocks is low and constitutes around $10 \%$ to $25 \%$ of this formation. The more we move toward the lower side of the flow, it decrease both in amount and also the size of pieces gets smaller which is one of the specifications of nuéeardente deposits. In the terminal part, there are no large blocks and only small grained pyroclasts exist.

By passing them in lower parts, running waters create some stratification and put alluvial pieces as big as fist and larger within the matrix white Tuffs, and at the end they turn into white sediments like kaolinite that whitens the hand.

The deposits of Shirvandareh's nuéeardente is white yellowish, and it is a heterogeneous mixture just like Mue'el formation. When replacing this formation, the heat rate was so high that the particles welded and in this way a kind of hardness and accretion was formed in these deposits. The presence of upright walls higher than $50 \mathrm{~m}$ is a proof of this claim (Figure 10).

Of the interesting points about Shirvandareh's nuéeardente is layered shape (Figure 10). It seems that these pyroclastic deposits were created during several occasions.

Each layer starts with coarse-grained fragments in base, and then gradually it becomes fine grained. Also under each coarse layer, a thick layer of brightly colored fine grained soil is seen that we consider as stopping of explosive activity and consequently the erosion of available deposits. Considering the alternation of pyroclastic deposits in Shirvandareh (Figure 9), the levels of nuéeardente could be considered as multistage [1].

First stage-The base of the first stage deposits is not accessible and consequently determining its exact thickness is not possible, but like nuéeardente deposits of Mue'el Valley coarse-grained fragments are located on a matrix of fine grained pyroclastic materials, including ash, lapilli, and small hot rocks, that is deposits of ash cloud and

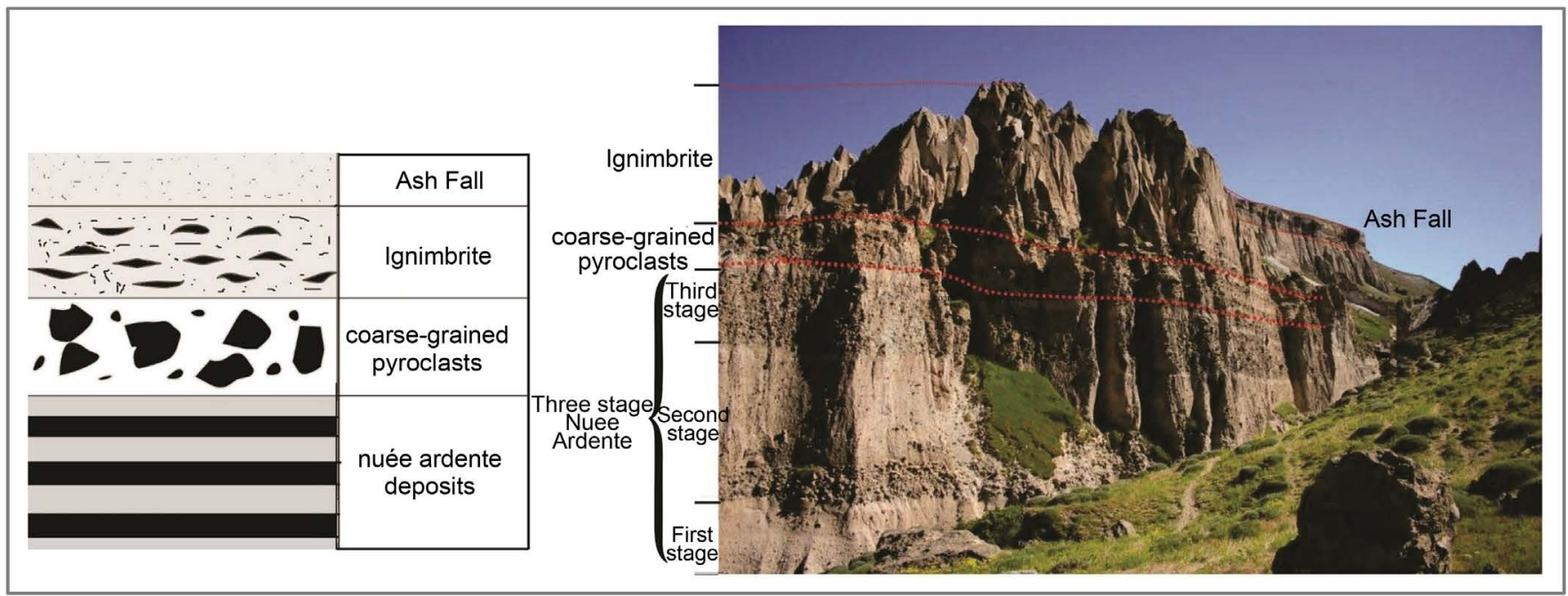

Figure 10. The welded, upright and relatively hard walls in Shirvandareh. 
blocks. But its coarse-grained fragments (weighing 15 to 20 tons) are rare and lower than next stages. Coarse-grained fragments are relatively round and cracked and fine grained fragments are partially sticking that indicate their somewhat high temperature (around $500^{\circ} \mathrm{C}$ ) which totally suggests semi-molten rocks that headed valley path and were crushed strongly while moving.

Second stage-The thickness of this layer is about $37 \mathrm{~m}$, and in it coarse-grained fragments are smaller than the first stage but their percentage is higher. The deposits of this stage relatively show graded bedding, and fine grained fragments indicate good agglutination.

Stage three-Its thickness is more, but it is rather weaker than other layers, and unlike the second layer its coarse-grained fragments are more, it lacks certain grading. Because of weakness and water flow effect, beautiful fairy chimneys have appeared in it (Figure 8). This layer was created due to explosion and severe smashing of margin rocks of caldera.

According to the above explanation, it could be imagined that mentioned events were related to the explosion of the forming dome on new caldera's sidelines. The first caldera caused the smashing and creation of the first stage's deposits and later explosions were resulted from dome's growth and blocking of outlet and it's re-opening. In each stage very sever explosions caused destruction and avulsing part of marginal rocks of the second caldera, and its ingredients have passed Shirvandareh's way with high speed and heat. The presence of a greater number of coarse-grained fragments of upper layers is a trace of increasing explosion in the place. It seems, by considering the erosion traces on some layers' surface, the explosions were distanced and dome's growth was happening slowly. It reveals peléan type activity altogether.

By comparing deposits of the two nuéeardentes of Mue'el Valley and Shirvandareh Valley, we observe that the extent, thickness, and size of blocks (presence of pieces larger than 8 tons) are higher in Shirvandareh than Mue'el Valley. Also by considering higher levels of pieces' adherence and hardness of deposits, it should be concluded that the temperature of this complex was higher than Mue'el Valley, and in general the power of Shirvandareh's nuéeardente is more than Mue'el Valley's.

At the present on the foot of this valley, there are two important and hot springs named Ghotursoee Spring and Chaikhaneh and an installation by the same name receives passengers.

\section{Conclusions}

According to the above explanations, it seems that mentioned events were related to the peléan type explosion of Aghandagh Mount which happened because of the forming dome on new caldera's sidelines. By surveying present rocks in these pyroclastics and their similarity to constituent rocks of the main cone of Sabalan, it can be concluded that the explosion has happened in the upper side of main cone of Sabalan and in the edge of second caldera and it has scattered the pieces of last pre-caldera series and main cone around. 
Considering the mentioned contents about nuéeardentes of Mue'el Valley and Shirvandareh, it is necessary to add up these points for comparison:

First, the distance between starting points of these two nuéeardentes is around $9 \mathrm{~km}$.

Second, the path of these two clouds is in parallel and overlooking to Meshkinshahr plain and located in valleys on the northern foot of Sabalan.

Third, by the subsidence of new caldera, breakings and faults appeared in the region and the most prominent of them was the creation of Shirvandareh and Mue'el Valley. Both of them were paths of nuéeardentes' movements.

Fourth, it seems that the two nuéeardentes of Mue'el Valley and Shirvandareh Valley have appeared simultaneously with the second caldera's subsidence. With this subsidence, some apertures for the exit of available gases above the magma chamber were opened and great explosions due to the sudden release of hot gases along with rock fragments created the nueéardentes of Mue'el Valley and Shirvandareh.

Fifth, considering the situation of Shirvandareh that is closer to Sabalan Soltan (main), the explosion intensity was higher in this place and the number of explosions was more than Mue'el Valley. While nuéeardente of Mue'el Valley that is farther from Sabalan and located in the middle of Aghandagh and Janavardagh has a far lower mass.

Sixth, similar to severe world volcanic explosions that lead to the exit of ashes and ignimbrites and finally appearance of a dome, it seems that the last activity in Sabalan led to the formation of the Qare Gol dome that rose to the surface, in the form of a thick pulp from fractures of the second caldera.

\section{References}

[1] Didon, J. and Gemain, Y.M. (1976) Le Sabalan, Volcan Plio-quaternair de l'Azerbaidjan oriental (Iran); etude geologiqueetpetrographique de l'edifice et de son environnement regional. These de 3eme Cycle, Univ. Grenoble.

[2] Ghalamghash, J., Mousavi, S.Z., Hassanzadeh, J. and Schmitt, A.K. (2016) Geology, Zircon Geochronology, and Petrogenesis of Sabalan Volcano (Northwestern Iran). Journal of Volcanology and Geothermal Research, in Press. https://doi.org/10.1016/j.jvolgeores.2016.05.001

[3] Mousavi, S.Z. (2013) Volcanology and Petrology of Sabalan Volcano, North West of Iran. Ph.D. Dissertation, Department of Geology of Science and Research Branch, Islamic Azad University, Tehran.

[4] Shahbazi Shiran, H. and Shafaii Moghadam, H. (2014) Geochemistry and Petrogenesis of the Sabalan Plio-Quaternary Volcanic Rocks: Implication for Post-Collisional Magmatism. Irananin Journal of Crystallography and Mineralogy, 22, 57-68.

[5] Emami, M.H. (2000) Magmatism in Iran. The Organization of Geology and Mineral Exploration of Country.

[6] Ogburn, S.E., Loughlin, S. and Calder, E.S. (2015) The Association of Lava Dome-Growth with Majorexplosive Activity (VEI $\geq 4$ ): Dome Haz a Global Dataset. Bulletin of Volcanology, 77, 1-17. https://doi.org/10.1007/s00445-015-0919-x

[7] Alberti, A.A. and Stolfa, D. (1973) First Data on the Savalan Volcano (Eastern Azerbaijan, Iran): The Upper Series. Rendicontidella Societa Italiana di Mineralogia e Petrologia, 29, 369-385.

[8] Alberti, A.A., Comin-Chiaramonti, G., Sinigoi, S. and Zerbi, M. (1976) On the Magmatism 
of the Savalan Volcano (North West Iran). Rendicontidella Societa Italiana di Mineralogia e Petrologia, 32, 156-168.

[9] Keller, E.A. and DeVecchio, D.E. (2012) Natural Hazards. 2nd Edition, Prentice Hall, Upper Saddle River.

[10] Sulpizio, R., Dellino, P., Mele, D. and La Volpe, L. (2008) Generation of Pyroclastic Density Currents from Pyroclastic Fountaining or Transient Explosions: Insights from Large Scale Experiments. IOP Conference Series. Earth and Environmental Science, 3, 12-20. https://doi.org/10.1088/1755-1307/3/1/012020

[11] Lacroix, A. (1904) La Montagne Peléeetseséruptions. Masson et Cie, Paris.

[12] Lacroix, A. (1930) Remarques sur les materiaux de projection des volcan et sur la genese des rochespyroclastiqueq'ill constituent. Bulletin de la Société Géologique de France, Livre Jubilaire Centenarie, 11, 431-472.

[13] Bardintzeff, J.M. (1999) Vulkanologie. Spektrum Akademischer Verlag, Heidelber.

[14] Calder, E.S., Lavallée, Y., Kendrick, J.E. and Bernstein, M. (2015) Lava Domeeruptions. In: Sigurdsson, H., Houghton, B., Rymer, H., Stix, J. and McNutt, S., Eds., Encyclopedia of Volcanoes, 2nd Edition, Academic Press, San Diego, 343-362. https://doi.org/10.1016/B978-0-12-385938-9.00018-3

[15] Carey, S. and Sigurdsson, H. (1985) The May 18, 1980 Eruption of Mount St. Helens 2. Modeling of Dynamics of the Plinian Phase. Journal of Geophysical Research, 90, 29482958. https://doi.org/10.1029/JB090iB04p02948

[16] Carey, S. and Sigurdsson, H. (1989) The Intensity of Plinian Eruptions. Bulletin of Volcanology, 51, 28-40. https://doi.org/10.1007/BF01086759

[17] Jousset, P., Pallister, J. and Surono (2013) The 2010 Eruption of Merapi Volcano. Journal of Volcanology and Geothermal Research, 261, 1-6. https://doi.org/10.1016/j.jvolgeores.2013.05.008

[18] Pallister, J.S., Schneider, D.J., Griswold, J.P., Keeler, R.H., Burton, W.C., Noyles, C., Newhall, C.G. and Ratdomopurbo, A. (2013) Merapi 2010 Eruptio: Chronology and Extrusion Rates Monitored with Satellite Radar and Used in Eruption Forecasting. Journal of Volcanology and Geothermal Research, 261, 144-152. https://doi.org/10.1016/j.jvolgeores.2012.07.012

\section{Submit or recommend next manuscript to SCIRP and we will provide best service} for you:

Accepting pre-submission inquiries through Email, Facebook, LinkedIn, Twitter, etc. A wide selection of journals (inclusive of 9 subjects, more than 200 journals)

Providing 24-hour high-quality service

User-friendly online submission system

Fair and swift peer-review system

Efficient typesetting and proofreading procedure

Display of the result of downloads and visits, as well as the number of cited articles

Maximum dissemination of your research work

Submit your manuscript at: http://papersubmission.scirp.org/

Or contact ojg@scirp.org 